Gi respons på artikler gjennom artiklenes kommentarfelt på tidsskriftet.no.

Innleggene publiseres fortløpende på Tidsskriftets nettside og et utvalg

av innleggene publiseres også i papirutgaven i spalten «Brev til redaktøren».

Redaksjonen forbeholder seg retten til å foreta redaksjonelle endringer.

Forfattere av vitenskapelige artikler har tilsvarsrett, jf. Vancouver-gruppens regler.

\section{Re: Smale legemidler}

I en artikkel i språkspalten konkluderer Erlend Hem og Steinar Madsen med at betegnelsen smale legemidler er en velegnet oversettelse av begrepet orphan drugs (1). Jeg deler ikke denne oppfatningen. Det europeiske legemiddelbyrå bruker betegnelsen legemidler til sjeldne sykdommer («medicines for rare diseases») om orphan drugs (2). I Legemiddelmeldingen brukes betegnelsen legemidler til sjeldne sykdommer (3), og i legemiddelforskriftens § 15-7 er orphan drugs oversatt til legemidler mot sjeldne sykdommer (4). Det at et legemiddel gis status som orphan drug er direkte knyttet til at tilstanden det er aktuelt å behandle er definert som en sjelden sykdom (5), og det virker søkt å introdusere begrepet smalt i denne sammenheng. Betegnelsen legemidler til sjeldne sykdommer er innarbeidet og er mer dekkende enn betegnelsen smale legemidler.

\section{Jan Frich}

jan.frich@medisin.uio.no

Jan Frich (f. 1970) er professor ved Universitetet i Oslo.

Ingen oppgitte interessekonflikter.

\section{Litteratur}

1. Hem E, Madsen S. Smale legemidler. Tidsskr Nor Legeforen 2016; 136: 241

2. Forskrift om legemidler (legemiddelforskriften). https://lovdata.no/dokument/ SF/forskrift/2009-12-18-1839 (19.2 2016).

3. Legemiddelmeldingen - Riktig bruk - bedre helse. Meld. St. 28 (2014-2015) www.regjeringen.no/no/dokumenter/meld.-st.-28-20142015/id2412810/ (4.3.2016). 4. Medicines for rare diseases. www.ema.europa.eu/ema/index.jsp?curl=pages/ special_topics/general/general_content_000034.jsp\&mid=WC0b01ac058002d4eb (19.2. 2016).

5. Heiberg A, Frich J, Røttingen J-A. Sjeldenhet-eget kriterium ved prioritering? Tidsskr Nor Legeforen 2014; 134: 534-6.

\section{Re: Smale legemidler}

Viser til artikkel i språkspalten der Erlend Hem og Steinar Madsen foreslår å bruke begrepet smale legemidler som norsk betegnelse på orphan drugs (1), og Jan Frichs kommentar til artikkelen, om at det norske begrepet på orphan drugs bør være legemidler for sjeldne sykdommer/diagnoser.

Nasjonal kompetansetjeneste for sjeldne diagnoser, NKSD, støtter det siste. For oss som jobber i sjeldenfeltet er det av stor betydning at orphan drugs kobles til behandling av sjeldne sykdommer. Både verdens største database på sjeldne diagnoser, Orphanet (2), og Orphan Europe (3) bruker orphan drugs om legemidler som er utviklet til behandling av personer med sjeldne sykdommer. $\AA$ ta $i$ bruk begrepet smale legemidler vil slik vi ser det virke fremmedgjørende, og bidra til at fokuset tas bort fra de mange med en sjelden diagnose.

Betegnelsen legemidler til sjeldne sykdommer er godt innarbeidet både nasjonalt og internasonalt, og bør derfor opprettholdes.

\section{Lena Lande Wekre \\ lenalw@ous-hf.no \\ Stein Are Aksnes}

Lena Lande Wekre (f. 1963) er lege, ph.d. og spesialrådgiver ved Nasjonal kompetansetjeneste for sjeldne diagnoser, Oslo universitetssykehus. Ingen oppgitte interessekonflikter.

Stein Are Aksnes (f. 1972) er leder ved Nasjonal kompetansetjeneste for sjeldne diagnoser, Oslo universitetssykehus.

Ingen oppgitte interessekonflikter.

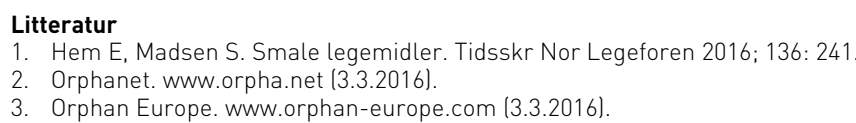

\section{Re: Klimaavtalen bra for folkehelsen}

Som leger har vi fått en ny forpliktelse skal vi tro Knut Erling Moksnes, som blir referert av Tidsskriftets Ellen Juul Andersen i nr. 3/2016 (1). Vi er altså forpliktet til å kjenne til sammenhengen mellom forbrenning av fossilt drivstoff, klimaendringene og sekundære negative helseeffekter. Siden utgangspunktet for artikkelen er klimamøtet i Paris, går jeg ut fra at det dreier seg om en menneskeskapt global temperaturøkning på omtrent $2 \mathrm{C}^{\circ}$ eller mer som vi i første omgang må passe oss for. Siden vi nå er pålagt denne forpliktelsen av Moksnes, kunne det være greit om han konkret redegjorde for hvilke sykdommer vi som bor her i Nord-Europa vil pådra oss med et slikt varmere klima, og hvordan vi som leger skal planlegge tiltak mot disse.

Historisk har menneskene i Europa hatt erfaring med vel så høy temperatur som den de teoretiske temperaturmodellene til FN's klimapanel forespeiler oss. Tilfeldigvis falt denne varme perioden sammen med en usedvanlig sosial og geografisk fremgang i Norden for vel 1000 år siden. Tilbakegangen kom $\mathrm{i}$ «Den lille istid» som varte ved til ut på 1800-tallet (2). Hvis Moksnes eller andre i hans gruppe har historiske sykdomsdata som viser at helseproblemene var størst i den varme perioden og mindre under «Den lille istid», burde Tidsskriftets lesere bli informert. I våre dager kan vi registrere at dødeligheten er 20-24\% høyere om vinteren enn om sommeren (3).

Innlegget har en meningsløs sammenblanding av miljøproblemer og klimagassutslipp som om det dreier seg om sammenfallende problemstillinger. Generaldirektøren for Verdens helseorganisasjon påstår at 7 millioner mennesker dør av luftforurensning hvert år. Ifølge direktøren vil investeringer i klimagassreduserende tiltak gi bedre luftkvalitet (1). Det er enighet om at vanndamp og CO2 som utgjør $98 \%$ av klimagassene, ikke påvirker den lokale luftkvaliteten. Derimot påvirkes den av NOx fra dieselbiler som har relativt lavt CO2-utslipp og partikler fra vedfyring og svevestøv fra veitrafikk. Problemstillingen er aktualisert i Oslo ved at den nye byregjeringen vil forby kjøring med dieselbiler på enkelte kalde dager, men tillate vedfyring $i$ indre bydeler.

Sikker kunnskap om årsakene til klimaendringene foreligger fortsatt ikke, og leger har neppe mer kompetanse til å uttale seg om dette enn folk flest. I artikkelen oppfordres likevel Legeforeningen og leger i samfunnsmedisinske stillinger - på ryggmargsnivå å snakke om helsekonsekvensene av klimagassutslipp, slik man gjør mot røyking. Jeg har vanskelig for å se at det foreligger noen medisinsk dokumentasjon som bør føre til at Legeforeningen engasjerer seg i disse spørsmålene.

\section{Astor Reigstad}

astorr@online.no

Astor Reigstad (f. 1937) er pensjonert overlege.

Ingen oppgitte interessekonflikter. 